\title{
Students' Degree of Possessing Digital-Citizenship Skills from Their Points of View at Al-Balqa Applied University
}

\author{
Mohammad Omar Al-Momani*, Mohareb Ali Alsmadi \\ Department of Educational Sciences, Ajloun University College, Al-Balqa Applied University, Jordan
}

Received March 16, 2020; Revised May 26, 2020; Accepted June 4, 2020

Copyright $\bigcirc 2020$ by authors, all rights reserved. Authors agree that this article remains permanently open access under the terms of the Creative Commons Attribution License 4.0 International License

\begin{abstract}
The study aimed to identify Al-Balqa Applied University students' degree of possessing digital-citizenship skills from their points of view, showing its relationship to the (gender and type of academic speciality) variables. The study used the descriptive curriculum where the information was collected through a questionnaire comprising (30) items distributed to three disciplines. The sample of the study comprised (400) male and female students who were selected randomly for the first semester of the academic year (2019-2020). The study concluded that Al-Balqa Applied -University students' degree of possessing digital -citizenship skills was "high" in all disciplines with an average (3.83). There were no statistically significant differences at the level of significance ( $\alpha=0.05)$ among the averages of the sample respondents' responses regarding the study variables. The study recommended increasing the technical support provided for Jordanian universities to develop digital skills and safety among students. This can be done by providing them with modern technological devices and implementing pioneering technological programs and projects in cooperation with private-sector institutions and companies. Besides, the study recommended raising awareness of the principles of digital citizenship to all segments of society and taking measures to ensure safety in the digital society. Also, preparing other studies on digital citizenship should be made to cover other stages of education, such as school and secondary education, postgraduate studies, and university professors.
\end{abstract}

Keywords Al-Balqa Applied University Students, Degree of Possession, Digital- Citizenship Skills, Gender, Information and Communication Technology (ICT)

\section{Introduction}

The past two decades had witnessed successive changes in ICT (Information and Communication Technology), accompanied by the development of the learners' skills in dealing with technological communication processes. The technological revolution has resulted in positive behaviours, if exploited optimally, and negative behaviours if its users rebel against the ethical rules governing the human- life affairs (Assayed Mahmoud, 2016) [1].

Today, the university student has become more open to the technology revolution and sources of information because of the growing requirements and successive developments of the educational process. It is because most of the educational university courses are moving towards a trend that is displayed within mixed learning environments to get flexible, efficient and effective educational style. Thus, universities shifted from the traditional style to the e-learning one facing many difficulties like lack of teachers' skills, ethical issues and others associated with this type of education. This study showed its impact on the learners, and the possibility of learning environments through matching recognized standards (Al-Mozan, 2018) [2].

Digital citizenship is closely related to education because it is the means that helps students, teachers, and parents understand what is needed to get proper use of technology. It is a way to prepare the students to take part in the service of their country through their optimal usage of it (Eurydice, 2013) [3].

No doubt spreading the culture of digital citizenship in our societies through education and curricula in school and university has become one base of life and an urgent necessity. This must be transformed into educational projects, cooperating with civil society and media 
institutions to protect societies from the negative effects of technology and build a national digital economy (Froehlich, 2012) [4].

Digital citizenship is not a modern concept. It had been addressed by many researchers for several years. However, the concept has not been crystallised as comprehensive as it is now. The experts have already addressed some of its elements, whether they are isolated or integrated. Some of them wrote about the digital divide, others were interested in digital access, and some wrote about digital literacy. Recently, experts have paid attention to digital codes of conduct and preventive measures to ensure the security of individuals, devices and networks (Assayed Yousry, 2016) [5].

Since knowledge is an essential form of financial and human principal, building knowledge societies begins with the acquisition and dissemination of knowledge through education and training. And then, comes the transfer and absorption of knowledge to others because economic, social, cultural and scientific growth is based on the accumulation and employment of knowledge. Generating knowledge can be fulfilled through scientific research, creativity, innovation, and cognitive contribution. Using modern technologies increases the return on investment, leading to the sustainability of growth in society, driven by productive human capacities that contribute to the advancement of societies (Al-Mozan, 2018) [2].

Today, the internet has become a major feature of the daily life of individuals. It has been spread by the use of electronic applications and means in various fields, such as business and education, and by various groups in society. And despite the many positive effects of using these electronic applications, there are a lot of internet risks. These risks required raising awareness of how to deal with them to employ them in the best way. One of the most important concepts that have attracted the attention of researchers is digital citizenship which confers safe usage within a moral and legal environment (Al-Sulaihat et al., 2018) [6].

Considering the digital age and the spread of information and communication technologies, citizenship has taken on a new form consistent with life and the demands of citizens. It has become a modern necessity to develop a general framework to educate the citizen, especially young people, about the controls of dealing with these technologies in terms of triple rights, obligations, and duties to help make the most of their advantages, and to ensure protection from their dangers when preserving the value and behavioural aspect of digital dealings (Al-Masri and Sha'at, 2017) [7].

The Internet and digital communications revolution also contributed to the spread and development of social media and the processes of accessing information sources with ease and speed. This information revolution has positive effects on the individual and society if the means of communication and modern technology are fully exploited and used. However, their negative effects are highlighted because of a lack of adherence to the ethical rules, controls, and laws in our Arab societies that regulated our human life affairs (Al-Mallah, 2017) [8].

Digital citizenship is an additional dimension of citizenship that is constantly strengthening according to the changes in societies. The technological change that has occurred in societies has reflected citizenship in a recent concept that shares with citizenship several factors, including their association with the existence of society. Both are based on a set of rights and duties and call for a balance between them. Likewise, both citizenship and digital citizenship require the participation of members of society, calling for a commitment to a set of ethical principles in the interaction of individuals. Besides, both citizenship and digital citizenship require learning their principles through socializing institutions (Choi, 2016) [9].

\section{Components, Hubs, Elements, and Dimensions of Digital Citizenship}

Despite the diversity of literature that referred to the components of digital citizenship, most of them have agreed on a set of components, elements, and hubs, as explained by (Al-Mozan, 2018 [2]; Al-Asmari, 2015 [10]; Al-Mallah, 2017 [8]; Al-Masalmani, 2014 [11] ; Ribble, 2012 [12]; Ribble \& Bailey, 2005 [13] ; Couros \& Hildebrandt, 2015 [14] ; Ribble, 2016 [15]):

2.1. Digital Etiquette: It means that digital citizens show and follow acceptable behavioural norms in the virtual world.

2.2. Digital Commerce: It means consumers are aware of the correct processes of buying and selling online and following the correct procedures that prevent fraud.

2.3. Digital Responsibility: It is for users of digital technology to take responsibility for their electronic business, besides being aware of the legal implications of them when violating regulations.

2.4. Safety and Health: It calls for attention to physical safety when using digital instruments, and adopting behaviours that reduce the risk of bad postures and neurological disorders resulting from misuse.

2.5. Security and Self-Protection: It asks users to be aware of spare measures to protect themselves, and they install anti-virus software and other measures to protect digital data.

2.6. Digital Communication: It is the digital exchange between the sender and the receiver, and it is classified into simultaneous communication: as sending messages and includes immediate responses, asynchronous communication, and includes receiving 
information such as texts and voices.

2.7. Digital Literacy: It includes teaching and teaching technology, and how to use it.

2.8. Digital Access: It is full and equal to electronic participation and participation in society.

2.9. Digital Law: It is for the user to realize that the laws of the digital society must not be violated and that there are actions punishable by law.

\section{Study Questions}

Reality shows that the world is witnessing with the third millennium a boom in the means of communication among people. They have broken down barriers and made the world a small village, especially with the emergence of social networks as being a necessity for individuals, particularly among university students (Abu Al-Majad and Al-Yousef, 2018) [16].

Also, spreading the culture of digital citizenship among the various members of society, whether students or teachers, at school and university, has become an urgent necessity. It is a requirement in current scientific developments and their challenges to achieve the integration of the gap between them to establish a conscious generation in a safe environment. Hence, this study came to reveal the degree to which students Al-Balqa Applied students' degree of possessing digital- citizenship skills by answering the following questions:

3.1. Question 1: What is Al-Balqa Applied students' degree of possessing digital-citizenship skills from their points of view?

3.2. Question 2: Are there statistically significant differences among Al-Balqa Applied students' degree to possess digital-citizenship skills, from their points of view, following the gender (males or females) variable?

3.3. Question 3: Are there statistically significant differences among Al-Balqa Applied students' degree to possess digital-citizenship skills, from their points of view, because of the academic specialisation (scientific or humanitarian) variable?

\section{Study Objectives}

The objectives of the study were to develop the skills of digital citizenship among students of the Al-Balqa Applied University in Jordan. These were highlighted by revealing their possession of digital citizenship skills from their points of view. Besides, they were to identify the existence of statistically significant differences at the level of significance $(\alpha=0.05)$ attributed to (gender and type of specialisation) variables. This could guide students towards organizing social interaction based on digital communication, ensuring the exchange of information, ideas and feelings and directing them towards the rational use of technology. This reflects positively on social integration and reduces the negative aspects of digital communication. The study also came as an invitation to the various Jordanian universities, whether governmental or private, to play its desired role in the development of students and communities. It attempted to do so through the fulfillment of its main functions, including facing the manifestations of technological progress and addressing its various risks.

\section{The Study Significance}

The significance of this study theoretically refers to the following considerations:

1. The increasing demand for students to use modern technology that is one of the most important motives that led the researchers to raise awareness of digital citizenship skills.

2. Addressing an important component of the educational process at the undergraduate level that is university students.

3. Keeping pace with modern educational trends that call for preparing students to face the changes of the times.

Practically, it is hoped that this study will benefit the following:

- University: by directing it to provide students and faculty members with the necessary means that enables them to engage in the digital age.

- Faculty members: by directing those to acquire the necessary technical skills and help students possess them.

- Students: by allowing those to acquire the necessary skills and encouraging them to communicate in the digital age.

\section{The Study Limits}

6.1. Objective Limits: This was limited to identifying the Al-Balqa Applied students' degree of possessing digital -citizenship skills from their points of view and its relationship to (gender and the type of academic specialisation) variables.

6.2. Human Limits: This was limited to the students of Ajloun University College affiliated with Al-Balqa Applied University in all academic stages and specialisations.

6.3. Spatial Limits: The study was applied at Ajloun 
University College, Al-Balqa Applied University.

6.4. Time Limit: The study was applied in the first semester of the academic year 2019/2020.

\section{Terms and Procedural Definitions}

\subsection{Digital Citizenship}

It was defined as a social identity that is shared by all members of society regardless of gender, race, religion to involve several rights and duties. (Wang and Xing, 2018) [17]. It is a set of rules, controls, standards, ideas, and principles for optimal use. ISTE International Society for Technology in Education, as included in (Naji, 2019) [18] study, defined it as the proper, responsible, appropriate and safe behaviour towards technology.

It was defined by Shaqura (2017) [19] as the principles, behaviours, controls, and rules that male and female teachers must have. They inform them of their rights and duties in their use of digital technologies, promoting the optimal use of technology so they can face the manifestations of cultural pollution.

Al-Smadi (2017) [20] defined it as a set of standards that individuals must adhere to when using digital media. It is a set of rights that they should enjoy when dealing with them, and the duties that they must abide via using them.

Preddy(2016) [21] defined it as the rules of responsible and communication with technology. Dotter and et. al. (2016) [22] defined it as the set of controls and standards needed for optimal use of technology.

It was defined as the sum of the regulations, norms, and principles of the proper use of technology young and old citizens need to contribute to developing the nation ( $\mathrm{Al}$ Fayed, 2014) [23]. (Al-Masalmani, 2014) [11] also defined it as the responsible, ethical and safe use of ICT by individuals as members of the national society and as citizens of the global community.

(Kafafi, 2016) [24] defined it as belonging to a virtual society, including the rights, duties, and responsibilities of individuals towards this community, and active participation in this society.

And the researchers defined it procedurally as the degree to which the study members get by answering the study instrument prepared for this purpose.

7.2. Students of Al-Balqa Applied University: are all male and female students responding to the study are regular ones in different colleges of Al-Balqa Applied University, and various programs and different levels of study?

\section{Literature Review}

This section presents an overview of previous studies related to digital citizenship, which was referred to:

The study of Abu Al-Majd and Al-Yousef (2018) [16] revealed the reality of using social networks among students of the Faculty of Education at King Faisal University, Saudi Arabia. Also, it displayed how to use them in enhancing the dimensions of their digital citizenship. The study used a questionnaire as an instrument to cover (4) hubs of digital citizenship themes. The questionnaire was applied to a sample of (356) male and female students. The results of the study showed that social networks have a role in promoting the dimensions of digital citizenship. Besides, there are statistically significant differences among the responses of respondents about the dimensions of digital citizenship because of the gender variable in favour of males.

Melhem's (2018) [25] study aimed to identify the availability of digital citizenship skills in life skills and family education for secondary school students in Saudi Arabia, using the descriptive-analytical method, and preparing a list adopted digital citizenship skills, comprising (62) sub-skills distributed to (9) major disciplines, and the study found a weak distribution of digital citizenship skills in this course.

Mehdi's (2018) [26] study aimed to reveal the level of awareness of digital citizenship among users of social networks of students of Al-Aqsa University in Palestine, and its relationship to some variables. The researchers applied a questionnaire of (4) hubs of digital citizenship on a sample of 700 male and female students. The study revealed that awareness of digital citizenship reached $76.8 \%$, which is above average.

Bin Shams's (2017) [27] study aimed to describe and analyse the values of digital citizenship among students of the University of Bahrain. A random sample of (56) male and female students from scientific and literary streams were selected. The researchers also presented examples of the experiments of some Arab and foreign countries in promoting citizenship goals in the digital age within the school curricula. The results have shown a spread of digital -citizenship values among undergraduate students to support learning and training processes. They have measured the impact of their use of technological methods in the development of citizenship.

Al-Smadi's (2017) [20] study aimed to identify the perceptions of the Qaseem University students towards digital citizenship. It applied the study questionnaire to a random sample of (374) male and female students. The study results clarified that the perceptions of students of the Qaseem University towards digital citizenship were of an average degree.

Al-Masri's and Sha'at's (2017) [7] study aimed to identify the level of digital citizenship among a sample of Palestine University students, from their points of view. It followed the descriptive-analytical method. It applied a questionnaire of (68) items distributed to (9) hubs. The sample comprised (300) male and female students. The 
results showed that the total degree of digital citizenship among the respondents was $71 \%$.

A study was conducted to determine the relationship between the extent of learners' Internet interaction and their level of academic achievement, and degree of satisfaction with the course, and learning styles (The Cheng's \& Chau's, 2016) [28]. The study included a survey of 78 students in the digital citizenship course in one faculty of Education in Hong Kong. It showed that there is a statistically significant relationship between the extent of the students' Internet interaction, their academic achievement and degree of satisfaction with the course. Besides, there is also a statistically significant relationship between the learning styles of students and their level of online interaction.

Al-Zahrani's (2015) [29] study examined the factors that affect the degree of participation of university students in the digital society. The study included a survey of 174 students. It found that students had a good level in both attitudes towards the Internet, computer skills, and digital citizenship, especially concerning self-respect and respect for others on the Internet. The results also showed that there is a direct relationship between digital citizenship and computer skills, the average daily use of technology, and students' attitudes towards the Internet.

Gungoren's (2014) [30] study aimed to develop a scale to measure the levels of digital citizenship among students of the Faculty of Education at the Turkish University of Sakarya. It was to verify the validity of the measure and its ability to distinguish between levels of digital citizenship among learners. The study sample included 229 male and female regular undergraduate students in each of the programs: primary teaching, pre-school education, Turkish education, religion and ethics education. The developed scale has got a high consistency of (0.85) showing the reliability of the scale and the contrast ratio was $70.178 \%$ of the total variance. All this showed the validity of the metric applied in this study and the possibility of using it in other future studies.

Lyons's (2012) [31] study dealt with e-learners' behaviours in one of the American provinces and their relationship with the learner's gender and classroom. The results showed that the greater the classroom, problems of personal security, digital abuse, and digital piracy are, the less family's supervision is. As for the gender of the learner, male learners showed that they had more personal security and digital citizenship than the educated ones. Unlikely, there were no differences regarding family supervision. The study concluded that there is a need to raise awareness about digital citizenship among learners, parents, and teachers.

The study, presented by Clifton (2010) [32], came as an important study under the title "How effective is the digital citizenship curriculum in schools in urban areas?" The key research question was: Is there an effect of exposure to the digital citizenship curriculum on the normative behaviour of students in terms of the quality of technology use? The research used the semi-experimental approach that applied to a sample of 75 learners. The control group also included the same number of learners, which are 75 learners. The researchers' goal is divided into two parts: The first part is related to the pedagogical addition that the research will provide to the field of educational research in this field. The second one is related to measuring the impact of the digital citizenship approach on the use/misuse of technology and its adaptation and implementation of the educational process.

\section{Comments on Literature Review}

This study meets with the previous studies in its general framework as it was used to enrich the theoretical framework and in the study's development instrument.

This study is one of the first studies to discuss the Al-Balqa Applied students' degree of possessing digital-citizenship skills because of the peculiarity of their studies which imposes on them the increasing use of information and communication technology, and therefore this study could be besides the literature of the topic.

\section{Method and Field Procedures}

\subsection{Study Methodology}

The study used the descriptive developing -survey method and went through the following stages:

In the first phase, theoretical literature was collected to obtain full information on the subject. In the second phase, the method of selecting the community sample was described, defining the study instrument, describing its construction and application procedures, and determining the used statistical treatment.

\subsection{Study Community}

It represents all the students of Al-Balqa Applied University, in its various academic majors, who are approximately $(43,000)$ male and female students. This number is based on the latest statistics of the Department of Admission and Registration at Al-Balqa Applied University for the academic year (2019/2020).

\subsection{Study Sample}

The sample of the study was chosen to follow the random sample method. It comprised (400) male and female students from Ajloun University College in terms of different grades, academic levels, and academic specializations. Table 1 showed the distribution of the study sample according to its variables: 
Table 1. Distribution of the sample respondents by study variables

\begin{tabular}{|c|c|c|c|c|}
\hline Variable & Levels & Number & Percentage & Total \\
\hline \multirow{2}{*}{ Gender } & Male & 200 & $50 \%$ & \multirow{2}{*}{400} \\
\cline { 2 - 4 } & Female & 200 & $50 \%$ & \\
\hline \multirow{2}{*}{$\begin{array}{c}\text { Academic } \\
\text { Speciality }\end{array}$} & Scientific & 184 & $46 \%$ & \multirow{2}{*}{400} \\
\cline { 2 - 4 } & Humanitarian & 216 & $54 \%$ & \\
\hline
\end{tabular}

\subsection{Study Instrument}

The study instrument was constituted and developed by referring to the relevant previous studies such as (Al-Momani, 2019 [33]; (Al-Sulaihat et al., 2018 [6]; Shaqura, 2017) [19]. They formed a special questionnaire that measures the level of digital citizenship skills among Al-Balqa Applied University students in Jordan. From their perspectives, the initial questionnaire comprised (37) items divided into three disciplines: digital health and safety, digital rights and responsibilities, and digital communication and communication skills.

\subsection{Study- Instrument Validity}

The validity of the content was adopted by presenting the study instrument to (8) faculty referees. They are from faculty members of Al-Balqa Applied and Yarmouk Universities in the specialities of Measurement and Evaluation, Educational Technology, Curriculum and Instruction, Educational Administration, and Sociology. They expressed their opinions about the degree of identification regarding the suitability of the items to their domains and modification or addition or deletion of any of them. Some modifications were made to some of the items proposed by the referees holding Full- Professor rank. Thus, the questionnaire comprised, in its last form (30) items distributed equally across the three disciplines of the study.

\subsection{Study- Instrument Reliability}

To ensure the stability of the instrument, the stability coefficient was extracted using the Cronbach Alpha equation for the internal consistency of the instrument fields. Table 2 shows the values of the stability coefficients for the study instrument fields. The values of the stability factors for digital citizenship skills ranged from $(0.86)$ to $(0.91)$, and these factors are high and suitable for the study.

Table 2. The Stability Coefficients Values by using the Cronbach Alpha Equation

\begin{tabular}{|c|c|}
\hline The field & $\begin{array}{c}\text { Stability } \\
\text { coefficient }\end{array}$ \\
\hline Digital communication and communication skills & 0.910 \\
\hline Digital rights and responsibilities & 0.890 \\
\hline Digital Health and Safety & 0.860 \\
\hline
\end{tabular}

\subsection{Study Procedures}

- Reviewing theoretical literature and previous studies.

- Study instrument design.

- Ensuring the reliability and reliability of the instrument.

- Getting task-facilitating books.

- Distributing and applying the study instrument to the sample of the study as (437) questionnaires were filled by the sample respondents. And (37) questionnaire was excluded for its invalidity to get the last number (400) questionnaire.

- Uploading the questionnaires in the computer software using the statistical analysis program in social sciences (SPSS) and analyzing them and conducting the appropriate statistical treatments.

- Studying the results of each question separately.

- Discussing the results and planning recommendations.

\subsection{Statistical Processing Used}

Statistical methods were applied using the statistical package (SPSS) to answer the questions of the current study:

To answer the first question: arithmetic averages and standard deviations were extracted.

To answer the second and third questions: (Independent Samples T-Test) was applied to study the differences between the answers of the respondents on the fields of study according to the variables of the study.

The following criterion was used to judge the Al-Balqa Applied- University students' degree of possessing digital citizenship skills.

The Likert -Fifth Scale was used according to the following model:

\begin{tabular}{|c|c|c|c|c|}
\hline $\begin{array}{c}\text { Very } \\
\text { much }\end{array}$ & Significantly & Average & Weakly & $\begin{array}{c}\text { Very } \\
\text { weakly }\end{array}$ \\
\hline 5 & 4 & 3 & 2 & 1 \\
\hline
\end{tabular}

The degree of estimation was determined according to the following equation:

Maximum Response Score - Minimum Response Score $\div 3$

$$
5-1=4 / 3=1.33
$$

Thus, the following test was adopted for the degree of application of the instrument as a whole and the fields of study and items:

- If the mean value is less than (2.33), students' degree of possessing digital-citizenship skills is low.

- If the mean value is greater than or equal to (2.33) and less than (3.67), students' degree of possessing digital-citizenship skills is average.

- If the mean value is greater than or equal to (3.67), students' degree of possessing digital-citizenship skills is high. 


\section{Study Results and Discussion}

First, the results related to the first question which states: What is the Al-Balqa Applied- University students' degree of possessing digital citizenship skills from their points of view?

To answer this question, the arithmetic means and standard deviations have been comprehensively extracted for Al-Balqa students' responses, from their points of view, to the questionnaire items. These items belonged to the scale of the degree of possessing the digital citizenship skills to cover every domain of the study instrument.

Table 3 shows that the degree of possessing digital citizenship skills among Al-Balqa students was high. The field of "digital communication and communication skills" came in the first place. Secondly was the field of "digital rights and responsibilities." The third place was for "digital health and safety". The researchers attribute this to the respondents' growing awareness and responsibility about the dimensions of using extra communication means that reflect the individual's taste and his personality. Thus, most individuals are keen to follow the civilized method of interaction using technology. And this is also due to the values of socialization received by the individual. These values are about the distinction between social interaction of the personal or official level, and the difference in content, style, and restrictions governing it. The restrictions can be social, legal, and religious.

\section{Results related to each domain of the study instrument are discussed separately:}

\section{First Domain: "Digital Communication and Communication Skills"}

Table 4 shows that the degree of possessing the numerical skills in the study sample in total was high. The means ranged from (4.10) to (3.87). Considering the items, the widespread use of modern technology in the lives of students and their increasing reliance on it for scientific, entertaining and social purposes can explain this. However, students should be cautious when dealing with digital trade, as most students are unaware of the digital skills. Thus, students are keen to be cautious when tackling them, in order not to be victims of fraud, extortion, and blackmail.

Table 3. Arithmetic means and standard deviations comprehensively show Al-Balqa students' degree of possessing digital-citizenship skills from their points of view or each domain of study instrument in a downward order

\begin{tabular}{|c|c|c|c|c|}
\hline Rank & The domain & Arithmetic means & $\begin{array}{l}\text { Standard } \\
\text { Deviation }\end{array}$ & Degree of possession \\
\hline 1 & Digital communication and communication skills & 3.89 & 0.65 & High \\
\hline 3 & Digital Health and Safety & 3.79 & 0.59 & High \\
\hline
\end{tabular}

Table 4. Arithmetic means and standard deviations to the degree of possessing digital citizenship skills among students of Al-Balqa Applied University in Jordan

\begin{tabular}{|c|c|c|c|c|}
\hline Rank & Items in the field of communication skills and digital \\
communication & Means & $\begin{array}{c}\text { Standard } \\
\text { Deviation }\end{array}$ & $\begin{array}{c}\text { Degree of } \\
\text { Possession }\end{array}$ \\
\hline 1 & I find happiness in communicating with others online. & 4.10 & .840 & .480 \\
\hline 2 & My social media publications illustrate my beliefs and ideas. & 4.04 & .550 & High \\
\hline 3 & I understand what digital communication is and why it matters. & 4.00 & .690 & High \\
\hline 4 & I am interested in following the news through social networking & 3.99 & .500 & High \\
\hline 5 & Social media approximates distances & 3.93 & .510 & High \\
\hline 6 & I use email to send and receive emails & 3.84 & .580 & High \\
\hline 7 & I'm being abused by some people online. & 3.52 & .660 & Average \\
\hline 8 & I try to know more details about any of the sites I visit online. & 3.39 & Average \\
\hline 9 & I use digital -communication technologies like social networks to & 3.19 & Average & Average \\
\hline 10 & I browse different websites through surfing the internet & 2.87 & .520 & High \\
\hline
\end{tabular}


Second Domain: "Digital Rights and Responsibilities":

Arithmetic averages and standard deviations were calculated for the study sample. Table 5 shows that:

Table 5. Arithmetic averages and standard deviations to the extent of possessing digital citizenship skills among Al-Balqa students from their points of view of the items of the "field of digital rights and responsibilities" sorted downwardly according to their arithmetic averages

\begin{tabular}{|c|c|c|c|c|}
\hline Rank & $\begin{array}{l}\text { Items in the field } \\
\text { of } \\
\text { communication } \\
\text { skills and digital } \\
\text { communication } \\
\end{array}$ & Means & $\begin{array}{l}\text { Standard } \\
\text { deviation }\end{array}$ & $\begin{array}{l}\text { Degree of } \\
\text { Possession }\end{array}$ \\
\hline 1 & $\begin{array}{l}\text { I contribute to the } \\
\text { spread of the } \\
\text { culture of safe use } \\
\text { of technology }\end{array}$ & 4.08 & .590 & High \\
\hline 2 & $\begin{array}{c}\text { I participate in } \\
\text { addressing any } \\
\text { messages against } \\
\text { the sovereignty } \\
\text { and stability of the } \\
\text { country } \\
\end{array}$ & 3.98 & .710 & High \\
\hline 3 & $\begin{array}{l}\text { I know the legal } \\
\text { penalties for } \\
\text { cybercrime. }\end{array}$ & 3.91 & .500 & High \\
\hline 4 & $\begin{array}{c}\text { I understand the } \\
\text { dangers of } \\
\text { anonymous digital } \\
\text { relationships }\end{array}$ & 3.77 & .660 & High \\
\hline 5 & $\begin{array}{l}\text { I consult my } \\
\text { friends before } \\
\text { posting group } \\
\text { photos on social } \\
\text { media sites such as } \\
\text { Facebook. }\end{array}$ & 3.73 & .740 & High \\
\hline 6 & $\begin{array}{c}\text { I avoid the } \\
\text { methods of scams, } \\
\text { and deceptions of } \\
\text { which others are } \\
\text { victims } \\
\end{array}$ & 3.70 & .720 & High \\
\hline 7 & $\begin{array}{c}\text { I elegantly } \\
\text { communicate with } \\
\text { others via } \\
\text { electronic means }\end{array}$ & 3.69 & .560 & High \\
\hline 8 & $\begin{array}{c}\text { I get sure to } \\
\text { mention the source } \\
\text { of digital content } \\
\text { when I am using it. }\end{array}$ & 3.68 & 0.38 & High \\
\hline 9 & $\begin{array}{l}\text { I know how to } \\
\text { block digital sites } \\
\text { and unsafe } \\
\text { programs } \\
\end{array}$ & 3.59 & .580 & Average \\
\hline 10 & $\begin{array}{l}\text { I carefully use } \\
\text { emoticons when } \\
\text { communicating } \\
\text { with instant } \\
\text { messaging like } \\
\text { WhatsApp. }\end{array}$ & 3.22 & 0.61 & Average \\
\hline & Total Degree & 3.73 & 0.55 & High \\
\hline
\end{tabular}

Table 5 shows that the degree of possessing digitalcitizenship skills in the study sample of the field of digital rights and responsibilities in total was high. The average of the field as a whole was (3.73). All items in this domain got a "high degree", except for the last two items as they got an "average degree." The arithmetic means of the field items ranged from (3.22) to (4.08). The researchers attribute this to the level of technical awareness among the sample members, especially with the rapid development in various fields, being positively reflected on their technological level. Also, there is a spread of the concept of digital law and the decrease of illegal practices. It is because of the emergence of electronic crime laws that protect all society members from any attack on their privacy or any extortion process that may occur. Besides, students use technology for scientific, educational, social and entertaining purposes to develop their knowledge and capabilities.

\section{The Third Domain: "Digital Health and Safety":}

Arithmetic means and standard deviations were extracted in the study sample. Table 6 shows that:

Table 6. Arithmetic means and standard deviations to the extent of possessing digital citizenship skills among Al-Balqa Applied students from their points of view of the items of the field of "digital health and safety" sorted downwardly according to their means.

\begin{tabular}{|c|c|c|c|c|}
\hline Rank & $\begin{array}{c}\text { Items of the field } \\
\text { of health and } \\
\text { safety digital } \\
\end{array}$ & Mean & $\begin{array}{l}\text { Standard } \\
\text { deviation }\end{array}$ & $\begin{array}{l}\text { Degree of } \\
\text { possession }\end{array}$ \\
\hline 1 & $\begin{array}{l}\text { I do not view stored } \\
\text { information on } \\
\text { others' digital } \\
\text { devices without } \\
\text { their consent. }\end{array}$ & 4.90 & .660 & High \\
\hline 2 & $\begin{array}{l}\text { I believe that } \\
\text { penetrating other } \\
\text { people's } \\
\text { information is } \\
\text { immoral. }\end{array}$ & 4.84 & .620 & High \\
\hline 3 & $\begin{array}{l}\text { I avoid damaging } \\
\text { others' files in } \\
\text { computers. }\end{array}$ & 4.81 & .580 & High \\
\hline 4 & $\begin{array}{l}\text { I use good } \\
\text { passwords hard to } \\
\text { be broken through. }\end{array}$ & 4.74 & .670 & High \\
\hline 5 & $\begin{array}{c}\text { I keep an } \\
\text { appropriate distance } \\
\text { between me and the } \\
\text { computer screen. }\end{array}$ & 4.53 & .590 & High \\
\hline 6 & $\begin{array}{l}\text { I maintain privacy } \\
\text { when posting } \\
\text { information via } \\
\text { social media. }\end{array}$ & 4.31 & .540 & High \\
\hline 7 & $\begin{array}{l}\text { I get breaks when } \\
\text { continuously } \\
\text { working using } \\
\text { technology. }\end{array}$ & 4.15 & 0.71 & High \\
\hline 8 & $\begin{array}{l}\text { I get sure to have } \\
\text { extra copies of the } \\
\text { stored data. }\end{array}$ & 4.02 & 0.73 & High \\
\hline 9 & $\begin{array}{l}\text { I check email } \\
\text { attachments before } \\
\text { opening them. }\end{array}$ & 3.90 & 0.60 & High \\
\hline 10 & $\begin{array}{l}\text { I make sure to turn } \\
\text { on the right lighting } \\
\text { on the screen to } \\
\text { reduce dazzle. }\end{array}$ & 3.83 & 0.50 & High \\
\hline & Total Degree & 4.40 & 0.57 & High \\
\hline
\end{tabular}


Table 6 shows that the degree of possessing the digital citizenship skills among the study sample of the field of digital health and safety as the total was high. The means were (4.24) and all items in this area got a "high degree". The averages for the items of the field ranged from (3.83) to (4.90). And this is because of the awareness of the importance of using technology and of respecting the privacy of individuals, not viewing them except with their consent. This is because of the scientific and technological progress that the Hashemite Kingdom of Jordan is leading towards educating individuals, especially students at different academic levels. There is an increasing knowledge of the sample individuals to protect their devices and their data from viruses and malware. It is due to the emergence of modern sites and software that look natural in appearance, but they have stolen users' data and penetrated their systems and personal accounts. And there is a commitment of the sample members to take caution when being busy and using technology to observe the rules of safety during use. The researchers believe that most of the study sample respondents are aware of the impact of negative behaviours which make them constantly interested in securing their work. They are cautious with the spread of harmful programs that may harm individuals' private data, whether these programs are pictures, videos, conversations or others.

The results related to the second question which states: Are there any statistical differences at the level of significance $(\alpha=0.05)$ among Al-Balqa students' degree of possessing digital -citizenship skills from their points of view because of the gender variable (males and females)?

To answer this question, we applied independent samples of T- Test to study the differences between the responses of the respondents in the study domains according to the gender variable (males and females). (Table 7).

Table 7 shows that there are no statistically significant differences at the level of significance $(\alpha \leq 0.05)$ in the degree of possessing digital citizenship skills among students of Al-Balqa 'Applied University from their points of view attributed to the gender variable (males and females). All values of (T) are not statistically significant, and the researchers attribute this result to the fact that male and female students have advanced competencies in using modern and advanced technology, especially since there are many courses at Al-Balqa Applied University having been computerized, which has reflected on the students and their technological capabilities.

The results related to the third question: Are there any statistically significant differences at the level of significance $(\alpha=0.05)$ among Al-Balqa Applied students' degree of possessing digital -citizenship skills from their points of view regarding the type of academic specialisation (scientific and humanitarian) variable?

To answer this question, We applied independent samples of T-Test to study the differences between the responses of the respondents in the fields of study following the type of academic specialisation (scientific and humanitarian) variable? (Table 8)

Table 8 shows that there are no statistically significant differences at the level of significance $(\alpha \leq 0.05)$ in the degree of possessing digital citizenship skills among students of Al-Balqa University from their points of view because of the type of academic specialisation (scientific and human) variable. All $\mathrm{T}$ values were not statistically significant, and the researchers attribute this result to the fact that students, whether in scientific disciplines or humanities, possess advanced digital skills. This may be due to the presence of courses taught at Al-Balqa Applied University, which contributes to the technical development of students as a course. Computer skills, which are considered courses Jabbarah for all university students, as well as the means of modern technology have become accessible to everyone, which contributes to the technological development and technology for all members of society.

Table 7. Results of the application of (Independent Samples of T-Test) to study the differences between the answers of the respondents in the areas of study by gender variable (males, females)

\begin{tabular}{|c|c|c|c|c|c|c|}
\hline \multirow{2}{*}{ The domain } & \multicolumn{2}{|c|}{ Male } & \multicolumn{2}{|c|}{ Female } & \multirow{2}{*}{$\begin{array}{c}\text { Statistical } \\
\text { significance }\end{array}$} \\
\cline { 2 - 6 } & Mean & $\begin{array}{c}\text { Standard } \\
\text { deviation }\end{array}$ & Mean & $\begin{array}{c}\text { Standard } \\
\text { deviation }\end{array}$ & & 0.18 \\
\hline The field of health and digital safety & 4.77 & 0.61 & 4.84 & 0.68 & 1.45 & 0.13 \\
\hline The field of rights and digital responsibilities & 4.70 & 0.63 & 4.88 & 0.66 & 1.41 & 0.16 \\
\hline $\begin{array}{c}\text { The field of communication skills and digital } \\
\text { communication }\end{array}$ & 4.90 & 0.58 & 4.77 & 0.59 & 1.23 & 0.19 \\
\hline The instrument as a whole & 4.79 & 0.61 & 4.83 & 0.61 & 1.19 & 0 \\
\hline
\end{tabular}


Table 8. Results of applying (Independent Samples T-Test) to study the differences between the answers of the respondents to the fields of study according to the type of academic specialisation variable

\begin{tabular}{|c|c|c|c|c|c|c|}
\hline \multirow{2}{*}{ The domain } & \multicolumn{2}{|c|}{ Humanitarian } & \multicolumn{2}{|c|}{ Scientific } & \multirow{2}{*}{ Statistical } \\
\cline { 2 - 5 } & Mean & $\begin{array}{c}\text { Standard } \\
\text { deviation }\end{array}$ & Mean & $\begin{array}{c}\text { Standard } \\
\text { deviation }\end{array}$ & & significance \\
\hline The field of health and digital safety & 4.48 & 0.59 & 4.21 & 0.72 & 1.44 & 0.19 \\
\hline The field of rights and digital responsibilities & 4.59 & 0.71 & 4.49 & 0.70 & 1.23 & 0.16 \\
\hline $\begin{array}{c}\text { The field of communication skills and digital } \\
\text { communication }\end{array}$ & 3.84 & 0.60 & 4.11 & 0.58 & 1.27 & 0.14 \\
\hline The instrument as a whole & 4.30 & 0.57 & 4.27 & 0.61 & 1.28 & 0.17 \\
\hline
\end{tabular}

\section{Conclusions}

To sum up, this study highlighted the degree of possessing digital skills among Al-Balqa Applied students in Jordan which was high in all fields of study. Besides, there were no statistically significant differences at the level of significance $(\alpha=0.05)$ among the responses of the respondents following the different study variables. The study variables were gender (males and females) and the type of academic specialisation (scientific and humanitarian).

\section{Recommendations and Suggestions}

Considering the findings of the present study, we proposed the following recommendations:

- Increasing the technical support provided to Jordanian universities to develop digital skills and digital safety among students. This should be done by providing them with modern technological devices and implementing pioneering technological programs and projects in cooperation with private-sector institutions and companies.

- Raising awareness of the principles of digital citizenship to all segments of society and taking measures to ensure safety in the digital society.

- Preparing other studies on digital citizenship that cover other stages of education, such as school and secondary education, postgraduate studies, university professors, school teachers, principals, and others.

\section{REFERENCES}

[1] Assayed, Mohamed Abdel-Badie (2016). The role of new media in supporting digital citizenship among university students. Journal of Public Relations Research Middle East, (12), 99-102.

[2] Al-Mozan, Amal Bint Ali Bint Saad (2018). The degree represents the students of the humanities faculties at Princess Nora bint Abdulrahman University for the values of digital citizenship with the perception of the role of the university in promoting its values. Journal of Educational Sciences Imam Muhammad bin Saud Islamic University, (17), 167-342.
[3] Eurydice. (2013). Citizenship education at schools in Europe. Eurydice. The information networks on education in Europe. Cambridge: Cambridge University Press.

[4] Froehlich, D. (2012). NCTA web 2.0: Passport to digital citizenship: Participant manual. North Carolina Teacher Academy.

[5] Assayed, Yousry Mostafa (2016). A proposed program according to the model of reverse learning to develop the concepts and skills of digital citizenship among students of the Faculty of Education and their attitudes towards the practice of ethics. Arab Society for Educational Technologies, (29), 105-229.

[6] Al-Sulaihat, Rawan and et al. (2018). Degree of awareness of the concept of digital citizenship for undergraduate students at the Faculty of Educational Sciences at the University of Jordan, In the Proceedings of the Faculty of Educational Sciences conference: Vol.45. Education in the Arab World towards a Distinguished Educational System. (p.3). Amman: University of Jordan.

[7] Al-Masri, Marwan Sha'at, Akram Hassan. (2017). The level of digital citizenship among a sample of students of the University of Palestine from their point of view. Palestine University Journal for Research and Studies, 7, (2), 168-200.

[8] Al-Mallah, Tamer Maghawri. (2017). Digital Citizenship: Challenges and hopes Cairo: Al-Sahab Publishing House.

[9] Choi, M. (2016). A concept analysis of digital citizenship for democratic citizenship education in the internet age. Theory and Research in Social Education, 1, (1), 1-43. Retrieved from https://doi.org/10.1080/00933104.2016.1210549.

[10] Al-Asmari, Shahd Sae'ed (2015). Digital citizenship and the culture of safe use of the Internet for adults and children and the steps of protection through safety, education techniques. Faculty of Education: Princess Noura University.

[11] Al-Masalmani, Lamia. (2014). Education and digital citizenship. National Center for Educational Research and Development. Egypt, (47), 15-94.

[12] Ribble, Mike. (2012). Digital citizenship for educational change. NATIONAL Educational Technology standards Organization, 48 (4), 30-151. Retrieved from https://doi.org/10.1080/00228958.2012.734015.

[13] Ribble, M., \& Bailey,G. (2005). Developing ethical direction. Learning and leading with Technology, 32(7), 3638, April 2005. Retrieved from https://eric.ed.gov/?id=EJ69 7346.

[14] Couros, A. \& Hildebrandt, K. (2015). Digital citizenship education in Saskatchewan schools. CA: Saskatchewan 
Ministry of Education. 14.

[15] Ribble, M. (2016). Digital citizenship using technology appropriately. Retrieved from http://www.digitalcitizenship .net/

[16] Abu Al-Majd, Maha and Al-Yousef, Ibrahim. (2018). Social media networks and ways to employ them enhancing the dimensions of digital citizenship among students of the Faculty of Education, King Faisal University. Educational Journal - Sohag University, (56), 691-722.

[17] Wang, X., Xing, W. (2018). Exploring the influence of parental involvement and socioeconomic status on teen digital citizenship: A path modelling approach. Journal of Educational Technology \&Society, 21, (1), 186-199. Retrieved from https://www.jstor.org/stable/26273879

[18] Naji, Maha Mahmoud. (2019). Digital citizenship and its awareness among the students of libraries, documents and information department, Assiut University: An exploratory study. Scientific Journal of Libraries, Documents and Information, Cairo University, 1 (2), 71-122.

[19] Shaqura, Hana Hassan (2017). The role of secondary school teachers in Gaza Governorates in promoting digital citizenship to face the phenomenon of cultural pollution among students and ways to activate it (Unpublished Master Thesis). Palestine: Faculty of Education, Islamic University of Gaza.

[20] Al-Smadi, Hind Semaan. (2017). Perceptions of Qaseem University Students towards digital citizenship (A field study on a sample of Qaseem University Students). Journal of Psychological and Educational Studies, (18), 175-184.

[21] Preddy, Leslie. (2016). The critical role of the school librarian in digital citizenship education. Knowledge Quest, 44, (4), 4-5. Gale Academic OneFile, Accessed 26 Feb. 2020.

[22] Dotterer,George, et al. (2016). Fostering digital in the classroom. Education Digest Journal, 82, (3), 58-63.

[23] Al-Fayed, Mustafa. (2014). The concept of digital citizenship. New Education Website, the subject has been accessed and referenced on (8-9-2019) on the following link: https://www.new-edu.com/definition-of-digital-citizenship.
[24] Kafafi, Hanan Mustafa Mohammed (2016). A proposed concept to develop the awarrness of basic education students in the culture of digital citizenship. Journal of Arab Studies in Education and Psychology, (special issue), 345 - 378.

[25] Melhem, Bandar bin Mohammed Rashid. (2018). Evaluation of life skills and family education course in the inclusion's light of digital citizenship skills among secondary school students (Unpublished Master Thesis). Saudi Arabia: College of Education, Qassim University.

[26] Mehdi, Ghada Kamal. (2018). The level of knowledge of kindergarten teachers in Saudi Arabia on the dimensions of digital citizenship. Journal of Scientific Research in Education, 5 (19), 515-547.

[27] Bin Shams, Nada Ali Hassan (2017). Citizenship in the digital age: The Kingdom of Bahrain model. Bahrain: Bahrain Institute for Political Development.

[28] Cheng, G., \& Chau, J. (2016). Exploring the relationships between learning styles, online participation, learning achievement, and course satisfaction: An empirical study of a blended learning course. British Journal of Educational Technology, 47, (2), 257-278. Retrieved from https://doi.org/10.1111/bjet.12243.

[29] Al-Zahrani, A. (2015). Toward Digital Citizenship: Examining Factors Affecting Participation and Involvement in the Internet Society among Higher Education Students. International Education Studies, 8, (12), 203-217.

[30] Gungoren, Ozlem Canan. (2014). Digital citizenship. The Turkish Online Journal of Educational Technology-January 2014, 13, (1), 1-5. Retrieved from tojet@sakarya.edu.tr

[31] Lyons, R. (2012). Investigating student's gender and grade level differences in digital citizenship behaviour. Retrieved from ProQuest Digital Dissertations. (AAT 3524065).

[32] Clifton J, Boyle. (2010). "The effectiveness of a digital citizenship curriculum in an urban school" (Dissertation \& Theses Collection, Paper AAI3404228). Retrieved on January 4, 2015 from http://scholarsarchive.jwu.edu/dissert ations/AAI3404228.

[33] Al-Momani, Mohammed Omar Eid. (2019). Degree of vocational education teachers' practice in Jordan for digital citizenship skills. Researchers Journal in Humanities and Social Sciences, 8, (1), 55-69. 